\title{
MESENCHYMAL STEM CELLS IN THE COMPLEX TREATMENT OF TRAUMATIC BRAIN INJURY
}

\author{
${ }^{1}$ Shanko Y.G. https://orcid.org/0000-0002-4633-0369 \\ ${ }^{2}$ Krivenko S.I. https://orcid.org/0000-0002-6813-4465 \\ ${ }^{3}$ Goncharov V.V. https://orcid.org/0000-0003-3560-7892 \\ ${ }^{1}$ Novitskaya $\boldsymbol{V} . \boldsymbol{V}$. https://orcid.org/0000-0003-4603-0275 \\ ${ }^{4}$ Zamaro A.S. https://orcid.org/0000-0002-9938-7203 \\ ${ }^{1}$ Tanin A.L. https://orcid.org/0000-0003-2449-2129 \\ ${ }^{1}$ Nekhai M.A. https://orcid.org/0000-0002-4134-9570 \\ ${ }^{4}$ Tokalchik Y.P. https://orcid.org/0000-0001-9668-8011 \\ ${ }^{1}$ Novikova L.A. https://orcid.org/0000-0003-4733-6735 \\ ${ }^{5}$ Kolyadich Z.V. https://orcid.org/0000-0002-7775-3540 \\ ${ }^{4}$ Kulchitsky V.A. https://orcid.org/0000-0003-1223-646X
}

${ }^{1}$ Republican Scientific and Practical Center of Neurology and Neurosurgery, Minsk, Belarus

${ }^{2} 9$ th City Clinical Hospital, Minsk, Belarus

${ }^{3}$ City Clinical Hospital of Emergency Care, Minsk, Belarus

${ }^{4}$ Institute of Physiology, National Academy of Sciences, Minsk, Belarus

${ }^{5}$ State Institution "N.N. Alexandrov National Cancer Centre of Belarus”, Lesnoy, Minsk District, Belarus

vladi@fizio.bas-net.by

Relevance. The problem of effective prevention and treatment of traumatic brain injuries (TBI) of various etiologies has not been resolved in all countries of the world. Primary brain damage from trauma initiates secondary damage to the nervous tissue. As a result, the interaction of brain neural networks is disrupted and the control of somatic and visceral functions of the body is weakened. The article is based on our own clinical observations and comparison of results with literature data and provides discussion of the prospects for the use of cell technologies in prevention of fatal disorders of vital functions control in traumatic brain injuries.

Objective. To evaluate effectiveness of intranasal perineural implantation of mesenchymal stem cells (MSCs) in the complex therapy of patients with TBI.

Materials and methods. The technique intranasal perineural administration of MSCs was used in complex therapy of 15 patients with severe TBI. The patients were 19 $\div 69$ years old, 13 men and two women. A cell suspension was isolated from the adipose tissue of patient's abdominal wall and centrifuged for $10 \mathrm{~min}$ at $1500 \mathrm{rpm}$. The cell pellet was washed in phosphate buffered saline and DMEM. Cells were cultured in plastic culture flasks in humidified atmosphere with $5 \% \mathrm{CO} 2$ content. The cell mass was trypsinized according to standard technique and resuspended in physiological saline on the day of implantation. Dynamics of culture growth, pluripotency, phenotyping of MSCs were monitored. MSCs were injected under general anesthesia into the submucosa of nasal cavity 3-4 times with an interval of 3-7 days, depending on the growth rate of MSCs, in a single dose from $12.0 \times 106$ to $35.0 \times 106$ cells.

Results. The use of allogeneic and predominantly autologous MSCs of adipose tissue in the complex treatment of patients with severe TBI by intranasal perineural delivery to the area of traumatic brain injury does not cause complications and is a safe technique. 8 patients with severe TBI showed from 4 to 7 points according to the Glasgow Outcome Scale Extended, with an average of $5.4 \pm 1.1$ points after 6 months. The main result is that complex therapy, including intranasal implantation of MSCs in acute and subacute periods of severe TBI, contributes to survival of patients and restoration of neurological - including cognitive - functions control.

Conclusions. The effectiveness of intranasal perineural implantation of MSCs in the complex therapy of patients with TBI has been demonstrated. The mechanisms of the beneficial effects of perineural implantation of MSCs in patients with TBI require further research.

Keywords: traumatic brain injury, patients, cell therapy, intranasal technique, mechanisms.

Relevance. Traumatic brain injury (TBI) is currently one of the socially significant health problems in the world. TBI accounts for $9 \%$ of population deaths and about one third of all deaths from external causes. Injury, homicide and suicide are the leading causes of death in the US and EU in people under 45 years of age [1]. Every year in the world about 10 million people receive TBI, which leads to hospitalization or death [2]. TBI is sometimes called a "quiet epidemic" due to the growing scale of this problem and low public awareness of significance of the consequences [3].
Primary brain injury in TBI provokes secondary brain damage that develops as a cascade of multiple pathophysiological mechanisms, including cytotoxicity, gene activation, oxidative response, cerebral edema, and inflammation [2]. Functional restoration of damaged neuronal and glial structures is the main task of regenerative medicine, which considers the use of stem cells (SCs) as the most promising direction [4].

Most of the research in this area are carried out in experiments on animals [4-6]. The clinical implementation of these methods remains a problem and requires devel- 
opment of reliable methods for SCs delivery, the study of mechanisms of specific action of mesenchymal stem cells (MSCs) on tissues, and other issues, that limit successful implementation of the method in clinical practice $[7,8]$.

Pathophysiology of TBI. Although the brain damage associated with TBI is usually acute, the further pathophysiological response proceeds in two stages. The first stage is direct physical damage to cellular elements, microvasculature and blood-brain barrier (BBB) $[9,10]$. Primary TBI leads to ischemia, a decrease in oxygen and glucose delivery to cells, which changes respiration into anaerobic and leads to accumulation of lactic acid. Depletion of ATP reserves in cells is followed by disruption of membrane permeability, which is accompanied by the accumulation of calcium ions excess in cytoplasm and mitochondria and formation of free radicals, which enhance the damaging effect [11-15]. An intense local inflammatory reaction develops, aggravating the primary injury and increasing its area with the involvement of neurons and glia of neighbor tissues. Inflammatory response consists in activation and migration of leukocytes and microglia to the site of injury and release of cytokines possessing pro-inflammatory (IL-1, IL-6, IL-12, TNF $\alpha$, IFN $\alpha$, IFN $\beta$, IFN $\gamma$ ) and anti-inflammatory (IL-4, IL-10, TGF $\beta$, IL-10) functions. A cytokine storm, in addition to oxygen radicals, gaseous mediators, proteinases, chemokines and other factors with cytotoxic effects, multiplies the death of nerve and glial cells [13, 16-18]. This complex cascade is known as secondary brain injury in TBI. Astrocytes, which form the basis of the BBB and are a key link in brain defense, surround the damaged area with a kind of glial scar that protects the intact part of the brain after TBI. However, the formed scar restricts the influx of macrophages, immunocompetent cells responsible for removal of inhibitory myelin from the damaged area, which ultimately inhibits the process of functional recovery of damaged brain area [19-22] and restoration of BBB [23].

Effect of MSCs on focal brain lesions. MSCs are multipotent stromal cells that are extracted from virtually any mature tissue and have potential to differentiate into a variety of cell types, including osteogenic, adipogenic, cartilaginous, and neural [24-28].

MSCs are able to migrate to sites of brain damage [7, 29-32]. Ponte A.L. et al. (2007) showed that MSC migration depends on a number of chemical agents and growth factors [33]. Another mechanism involves vascular cell adhesion molecule VCAM-1 $[34,35]$. There is more evidence for how MSCs find damaged cells within healthy tissue. Introduction of MSCs into damaged tissue promotes endogenous tissue repair process by releasing active growth factors [36-39]. MSCs also have immunosuppressive properties that can be used to reduce secondary brain damage in severe TBI $[40,41]$.

The mechanisms of regenerative effect of MSCs in brain lesions are widely studied in experimental animal models. Until recently, it was believed that SCs administered intracerebrally migrate to TBI focus, where they survive for two months and differentiate into functional neurons, astrocytes, and oligodendrocytes [42]. However, this opinion is criticized because there is no clear evidence that SCs are capable of generating several deterministic subtypes of neurons with axons at the lesion locus, which form new synaptic contacts [43]. By the way, it has been shown in vivo that neuron-like cells derived from MSCs do not have the ability to generate an action potential $[44,45]$.

Transplantation of SCs activates efficiency of functioning of preserved neural networks, which contributes to restoration of sensory and motor functions and explains their reparative potential $[6,46]$. It is all the more difficult to imagine a different opinion, for example, on the activation of neurogenesis in the form that was completed at the embryonic stage of development at a low Hayflick limit (0.1) for nervous tissue [47]. From our point of view, neuroplasticity is not the ability to generate new neurons, but the ability to "reanimate" the functions of neural networks preserved after injury.

It has been established that MSCs, mononuclear cells of umbilical cord blood and bone marrow, are able to improve neurological function in experimental models of cerebral ischemia through a combination of effects such as neuroprotection, angiogenesis, immunomodulation and stimulation of neuronal plasticity, but these effects are not necessarily associated with the presence of cells at the site of injury [48-51]. These mechanisms of action are fully explainable by secretion of neurotrophic factors and immunomodulatory molecules by transplanted MSCs, the effect of which is additionally potentiated by microenvironment of damaged brain (paracrine mechanisms) [52]. It has been shown that MSCs exhibit reparative potential due to release of many neurotrophic factors (nerve growth factor, glial-derived neurotrophic factor, brain-derived neurotrophic factor, vascular endothelial growth factor, etc.) and the mechanism of exosome-mediated microRNA transfer to neurons and astrocytes [53-55]. It is believed that several injections are required to optimize release of required factors from MSCs [56]. These results support the idea that the presence of MSCs promotes restoration of nervous system functions through secretion of soluble growth factors $[39,57,58]$.

\section{MATERIALS AND METHODS}

15 patients with severe TBI (4-8 Glasgow Coma Scale (GCS) points) were selected in accordance with developed list of indications and contraindications for complex treatment with MSCs of adipose tissue. Patients were aged $19 \div 69$ years $(41.8 \pm 17.6$ years $), 13$ men, 2 women. $10(66.6 \%)$ of these patients received surgery due to intracranial hematomas and brain contusions, including 7 (46.7\%) patients subjected to decompressive hemicraniectomy. 
The biological material was prepared as follows. Adipose tissue from the patient's abdominal wall was excised with scissors under intravenous anesthesia, washed in phosphate buffered saline (Sigma-Aldrich, USA, $\mathrm{pH}=7.4$ ), placed for $30-40$ minutes in $0.075 \%$ type I collagenase solution (Sigma-Aldrich, USA) or for $30 \mathrm{~min}$ in $0.25 \%$ EDTA trypsin solution (Sigma-Aldrich, USA). Then an equal volume of DMEM medium (Sigma-Aldrich, USA) was added to neutralize enzyme activity. Resulting cell suspension was centrifuged for $10 \mathrm{~min}$ at $1500 \mathrm{rpm}$. The cell pellet was washed twice in phosphate buffered saline for $10 \mathrm{~min}$ at $1500 \mathrm{rpm}$ and then in DMEM medium, plated into plastic culture flasks, which were placed in humidified atmosphere with 5\% CO2 content (Revco Elite II incubator, USA). The medium was removed from the vials in 48 hours, cells were washed with phosphate buffered saline, $1 \mathrm{ml}$ of trypsin solution was added and incubated for three minutes at $37^{\circ} \mathrm{C}$. Then the cells were washed from trypsin and resulting precipitate, if necessary, was sown again in culture flasks. Cell mass was trypsinized according to the standard technique and resuspended in saline on the day of implantation of autologous MSCs in a specific TBI patient [59].

The cell material control algorithm included morphological analysis of MSCs; dynamics of culture growth; pluripotence; phenotyping of MSCs (CD90, CD105, CD13, CD44, CD73, CD29, CD34, CD45); percentage of viable MSCs; bacteriological culture to control sterility of MSCs. Preparation of MSCs took from 8 to 14 days from the collection of biological material.

Two (13.3\%) patients died after taking biological material before the start of cell therapy, two more (13.3\%) - before its end (1-2 MSCs injections were performed). These patients are not included in analytical design. Cell therapy was started on the 16-30th day from the moment of injury in $7(63.6 \%)$ patients, in the period from 2 to 12 months after the injury - in 4 (36.4\%).

Perineural implantation of autologous MSCs through the submucosal layer of nasal cavity was performed under general anesthesia using the endoscopic technique developed by the authors of the article. Endoscopic Karl Storz stand (Germany) was used. The area of brain damage and the side of predominant lesion were determined according to CT data. Taking into account somatotopic principle of MSCs distribution in brain, the zone of intranasal implantation was selected: receptor fields of the olfactory nerves in case of predominant lesion of supratentorial parts of brain and receptor fields of trigeminal nerves in case of predominant lesion of subtentorial parts.

MSCs were injected 3-4 times with an interval of 3-7 days, depending on their growth rate, in a single dose from $12.0 \times 106$ to $35.0 \times 106$ cells, with a total dose from $52.2 \times 106$ to $145.5 \times 106$ cells. One injection of allogeneic MSCs was performed before the start of therapy with autologous MSCs on the day of biomaterial sampling at a dose of $20.0 \times 106$ cells to reduce waiting period in the last five $(45.5 \%)$ observations. In another $(9.1 \%)$ case, due to biological limitations of conduction, three injections of allogeneic MSCs were administered at a total dose of $60.0 \times 106$ cells

Changes in the level of consciousness were assessed by GCS, features of neurological status, dynamics of changes on brain CT throughout the treatment period. Skull defect plastics was performed in all patients in need within 1.5 to 2.5 months after the injury. GCS treatment outcomes were assessed in 10 patients after 6 months (one patient received MSC therapy 12 months after injury).

\section{RESULTS AND DISCUSSION}

The use of autologous and allogeneic MSCs of adipose tissue in the complex treatment of patients with severe TBI by means of their perineural delivery to the area of traumatic brain injury turned out to be safe and did not cause complications.

Despite cell therapy with MSCs, one (10.0\%) patient died, vegetative state remained in one patient $(10.0 \%)$ after 6 months. Remaining 8 patients showed Glasgow Outcome Scale Extended, GOSE [60] score from 4 to 7 points, with an average of $5.4 \pm 1.1$ points after 6 months. The control group was selected by the "copy-pair" method, in the maximum similarity of age, sex, clinical condition of patients and $\mathrm{CT}$ picture of brain upon admission to hospital.

At this stage, it can be noted that a relatively early start of cell therapy contributed to restoration of higher level of cognitive functions. Those patients who received MSCs at a dose more than $80.0 \times 106$ had better neurological outcomes. Here is a brief example of clinical observation.

Patient $L$., 28 years old, received severe TBI on July 10, 2020. Operated, acute subdural hematoma on the left was removed, decompressive hemicraniectomy on the left was performed. Coma duration was 9 days. Biological material was taken from the patient in this state and $20.0 \times 106$ allogeneic MSCs were injected. Then, during the course of therapy, another $145.5 \times 106$ autologous MSCs were injected by three injections at weekly intervals. Plastic surgery of the skull defect was performed in two months after decompression. The patient's aphasic disorders were completely rebuilt, motor disorders recovered. Minimal limitation of movement in the right hand is maintained. Outcome assessment according to GOSE - 7 points (Fig. 1).

The use of MSCs in the late period (one year after suffering severe TBI) provided a patient with severe aphasic disorders with complete recovery of speech function. Here is a brief example of clinical observation.

Patient G., 39 years old, received severe TBI on June 29, 2018. Acute subdural hematoma removed, depressed fracture of the left temporal bone eliminated, then decom- 
pressive hemicraniectomy performed. Dynamic recovery of cognitive and motor functions was observed in postoperative period after 5 days of coma. However, speech did not recover one year after the injury, despite active training with a speech therapist. Biomaterial was taken on May 27, 2019 and three implantations of autologous MSCs of adipose tissue were performed in a total dose of $87.4 \times 106$ cells from June 09, 2019. Speech recovery occurred up to one month after cell therapy, although some reversal of speech dysfunction was noted after each administration of MSCs. Now speech has recovered, the GOSE score is 7 points (Fig. 2).

Thus, the conduct of complex therapy, including MSCs implantation in acute and subacute periods of severe TBI, contributed to survival of patients and recovery of neurological, including cognitive, functions in our study.

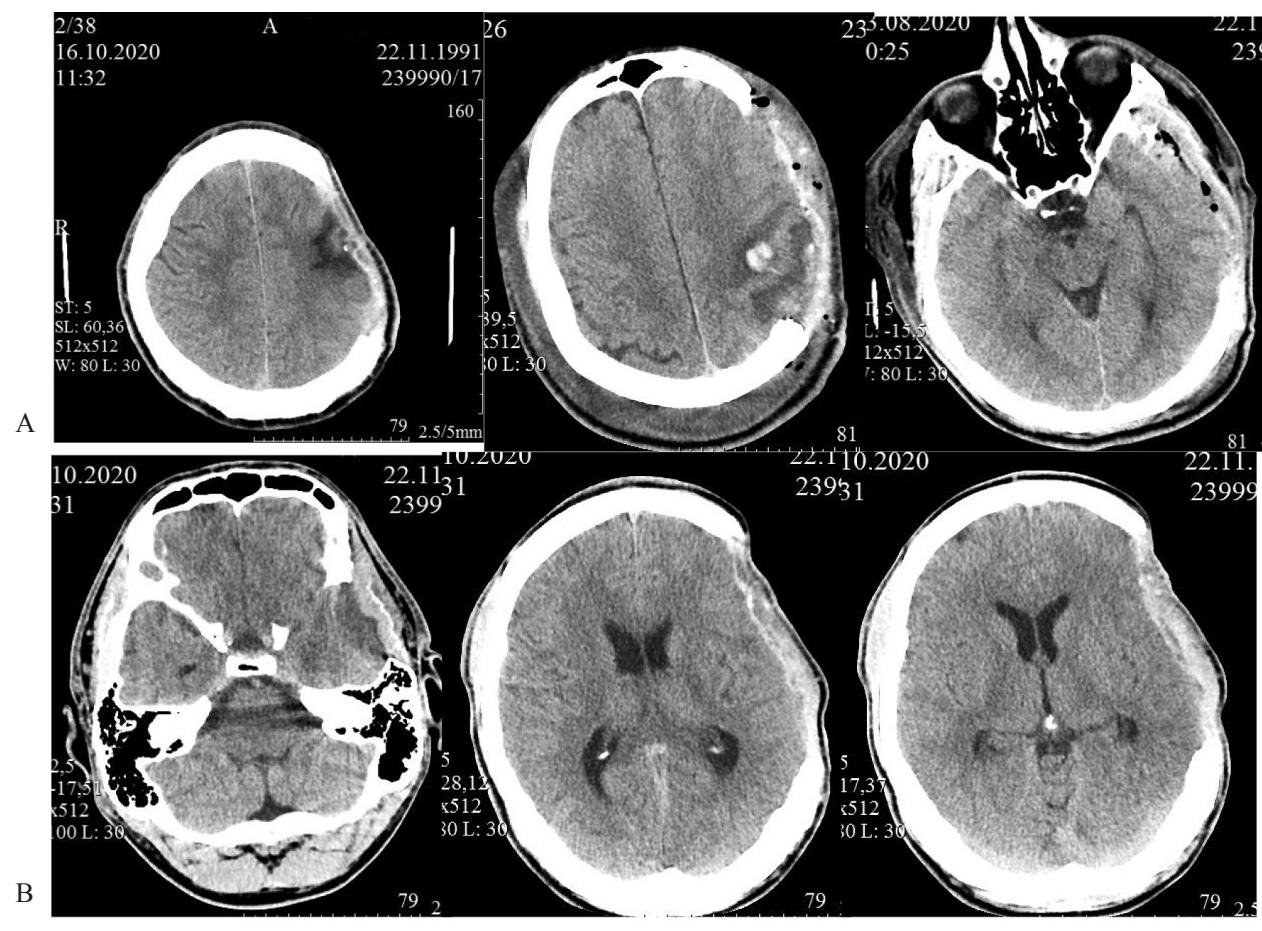

Fig. 1. Patient L., 28 years old. Severe TBI. A - Acute period, CT after decompression craniotomy, before cell therapy; B - CT after the end of cell therapy, before the plastic of the skull bone defect

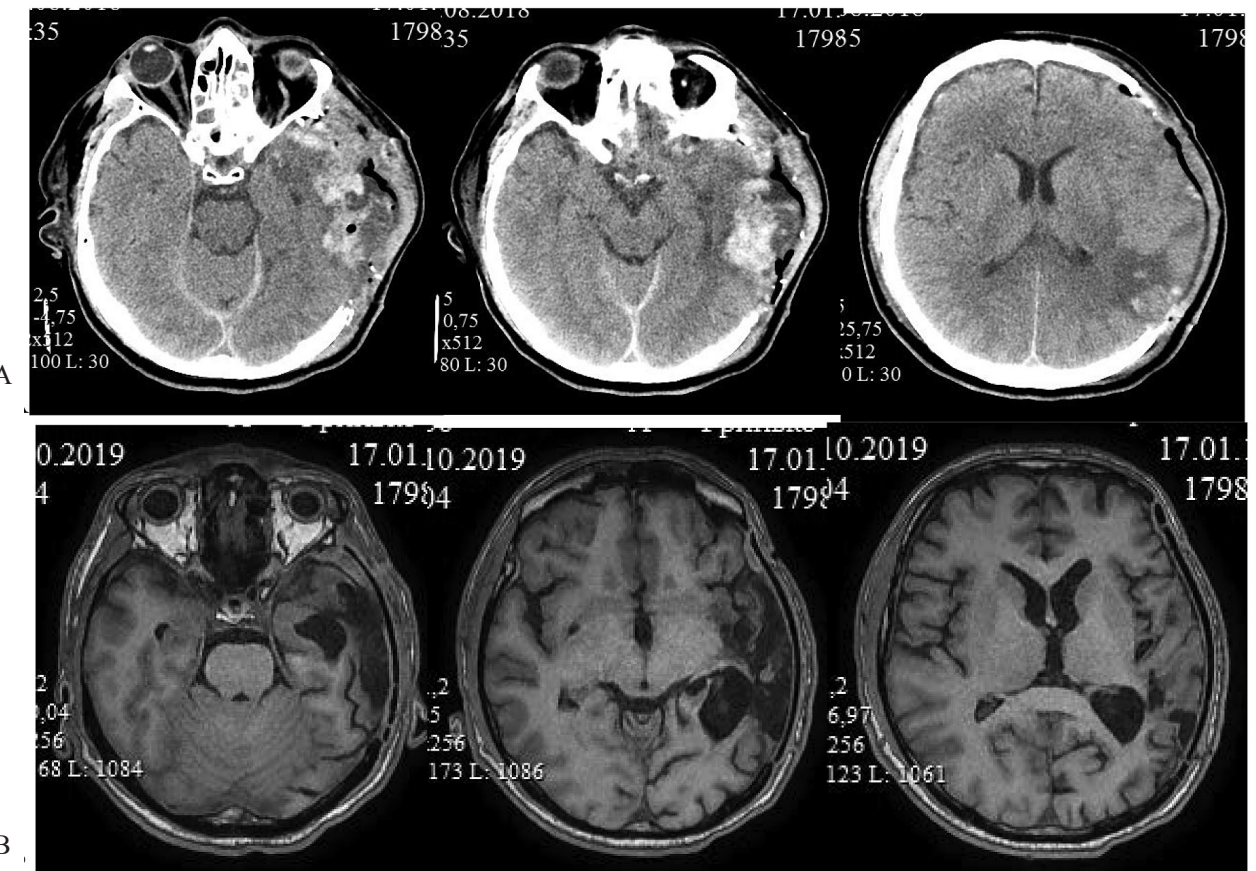

Fig. 2. Patient G., 39 years old. Severe TBI. A - Acute period, CT after decompression craniotomy, before cell therapy; C - CT after the end of cell therapy, after plastic surgery of the skull bone defect 
Intracerebral stereotaxic injection of SCs into the focus of cerebral infarction demonstrated significant positive effect on restoration of neurological functions upon initiation of cell therapy at the early stage of disease (first week) [61] and significant variability of recovery process upon initiation of cell therapy at the later stages of disease [62-66]. Some doubts are raised by the press reports about the positive effects of treatment within 3-8 years after the disease onset, when the processes of apoptosis and functional restructuring of the nervous system have already been completed. Despite the fact that intracerebral transplantation allows a large number of cells entering the lesion focus, this method is accompanied by uneven distribution of SCs in brain [67].

Intrathecal administration of SCs is accompanied by short-term fever and meningeal symptoms, but, in general, is an effective method of treatment $[68,69]$. The phenomena of meningism are caused by destruction of $\mathrm{SCs}$ in osmotic conditions of cerebrospinal fluid. Cranial movement of SCs against CSF flow during lumbar punctures is questionable. A certain effectiveness of this method is probably due to the influence of growth factors from the contents of exosomes released into cerebrospinal fluid after destruction of SCs.

Intra-arterial administration of SCs in focal brain lesions sometimes has a positive effect; however, less than $2 \%$ of the total amount of injected SCs accumulate in brain [70-73]. It is important that intra-arterial injection of SCs can lead to embolism, significant decrease in cerebral blood flow, and is accompanied by increase of mortality [67, 74].

Intravenous administration of SCs is the simplest method for delivering cellular material to brain lesions. It has been demonstrated [75] that SCs labeled with iron oxide nanoparticles, according to MRI data, in rare cases migrate to the focus of cerebral infarction after intravenous administration of SCs. A number of authors point at persistent or transient positive effects of intravenous cell therapy $[76,77]$, while other authors, on the contrary, point at their absence [78]. Rosado-de-Castro P.H. et al. [71] showed that intravenous injection of SCs leads to small accumulation in the affected hemisphere compared to intra-arterial route. But the final results of therapy in both groups [71] were very similar.

Kamiya N. et al. [79] showed that intra-arterial administration of SCs provides their higher content in brain and better results in comparison with intravenous administration. However, Vasconcelos-dos-Santos A. et al. [80] found that intravenous and intra-arterial infusions of SCs in the model of permanent ischemia are accompanied by equivalent recovery of brain functions with a low level of SCs deposition in brain (less than $2 \%$ of the total number of injected SCs). Zhang L. et al. [81] noted that intra-arterial, intravenous, intracerebral, intracisternal, and lumbar intrathecal delivery of SCs in an ischemic model led to similar structural improvements. Meta-anal- ysis of preclinical studies of stroke by Lees J.S. et al. has not revealed any effect of SCs delivery pathway on the effectiveness of cell therapy [82].

It is known that SCs migrate along the afferent perineural spaces and have positive taxis for damaged tissue [83]. The authors of the article proposed a hypothesis about the use of these properties for SCs migration to the brain $[84,85]$. The areas of olfactory and trigeminal nerves terminals were proposed as zones for implantation. By the way, there is a pool of endogenous olfactory SCs in nasal cavity [86]. Experiments on laboratory rats have shown the presence of somatotopic distribution of SCs in brain [87]. Injected of SCs into olfactory nerve receptor field led to distribution of fluorescent cells in supratentorial regions of brain, while SCs injection into the region of trigeminal nerve receptor endings was followed by SCs migration to the affected areas of posterior cranial fossa [87].

The technique of MSCs endoscopic intranasal implantation has been experimentally developed for clinical use [88]. Taking into account the properties of MSCs, it was assumed that the efficiency of delivery of implanted cells to the area of brain damage (cerebral infarctions, intracranial hemorrhages, TBI, and other brain diseases) will increase due to their directed migration along the afferent fibers of cranial nerves, which contributes to increase in the treatment effectiveness. It is necessary to implant MSCs in the region of receptor endings of olfactory nerves (upper and middle floors of the nasal cavity) when the destruction site is located in supratentorial parts of the brain. And it is advisable to implant MSCs in the region of receptor endings of trigeminal nerves (lower and middle floors of nasal cavity) or in the Meckel space when the destruction site is located in posterior cranial fossa. Such method of implantation will significantly reduce the amount of implanted material and surgical trauma to patients. The proposed technique for implantation of MSCs is distinguished by its simplicity of performing the manipulation for a trained neurosurgeon.

Schepici G. et al. [69] presented analysis of clinical studies on the use of SCs in TBI, registered at https:// clinicaltrials.gov/. The site has a list of clinical trials approved by local ethics committees - a total of 18 studies. No definitive conclusions have been drawn as the recruitment of patients continues [69].

C.S. Cox Jr et al. [89] implanted MSCs in 10 children with severe TBI with GCS score of 5 to 8 and followed them up for 6 months. 7 children showed positive result per GCS. The other three children did not have a significant improvement in their quality of life. None of the children died or suffered from side effects due to the use of MSCs in combination therapy. The same authors have used MSCs in the treatment of cerebral stroke in adults with positive results [89].

C.S. Cox Jr. et al. [90] assessed safety and efficacy of autologous bone marrow mononuclear cells (ABMMC) 
transplantation at high doses. 25 patients (aged 18 to 55 years) with severe TBI (GCS 5-8 points) were enrolled. Final doses of ABMMC $-6 \times 106$ cells $/ \mathrm{ml} / \mathrm{kg}, 9 \times 106$ cells/ $\mathrm{ml} / \mathrm{kg}$, or $12 \times 106$ cells $/ \mathrm{ml} / \mathrm{kg}$ in $0.9 \%$ saline containing $5 \%$ human serum albumin were injected intravenously. None of the patients experienced severe side effects after ABMMC transplantation., The pools of IL- $1 \beta$, IFN- $\gamma$ and $\mathrm{TNF}-\alpha$ showed a significant decrease in concentrations after ABMMC transplantation in patients, which corresponds to suppression of inflammatory response to trauma. In summary, ABMMC transplantation in patients with severe TBI is effective in maintaining brain function by attenuating inflammatory response [90].

The study by S. Wang et al. [91] was aimed at evaluating efficacy of cord blood MSCs transplantation in patients with TBI. Patients from the main group were injected four times with $2 \mathrm{ml}$ of suspension containing $1 \times 107$ MSCs through lumbar puncture for 5-7 days. These patients showed a significant improvement in motor function, sensitivity and coordination of movements, as well as improved mobility, communication and the ability to be independent after 6 months of MSCs addition to the complex therapy. In summary, transplantation of cord blood MSCs by lumbar puncture is associated with improved brain function after TBI [91].

Retrospective cohort study by G.P. Liao et al. [92] included 29 children (5-14 years old) on the first day of severe TBI (GCS 5-8 points). Patients from the main group were injected with ABMMC intravenously at the dose of $6 \times 106$ cells $/ \mathrm{kg}$ of body weight within 48 hours after injury. The volume of intensive care was significantly reduced to maintain normal intracranial pressure in 24 hours after $\mathrm{ABMMC}$ transplantation, and movement disorders began to recover in one week. These results are presumably due to therapeutic effect of cell therapy [92] by reducing the effects of inflammation in the early period of severe TBI [92].

C. Tian et al. [93] showed that the use of ABMMC has a window of effectiveness after TBI. ABMMC were implanted by lumbar puncture in 97 patients, 24 of whom were in vegetative state. Signs of recovery of brain functions were noted in 38 out of 97 patients in 14 days after transplantation. Specifically, 11 out of 24 patients in vegetative state showed improvement of consciousness level. Motor activity improved in 27 out of 73 patients with motor dysfunction. Younger patients showed more significant recovery than the elderly, and the effectiveness of cell therapy was the higher the earlier the implantation of cells was started.

Z.X. Zhang et al. [94] showed that the use of MSCs in patients with TBI is a safe and effective procedure that potentially accelerates recovery of brain function. The procedure consisted of injecting 107-109 MSCs directly into the damaged area of the brain during cranial surgery, followed by intravenous injection of 108-1010 cells. Cell therapy was administered to eight patients. There were no side effects and only one patient had two episodes of epilepsy in the first two months. The Barthel index in all patients have been constantly increasing during 6 months of treatment. The results of the authors' studies indicate that cell therapy in the treatment of severe TBI using adipose tissue MSCs is safe and does not cause complications. Perineural implantation of MSCs is capable of delivering biological material to critical areas of the brain, as evidenced by positive transplant result. The effect of cell therapy was obtained both in acute and long-term periods of TBI. The small size of the main group does not allow reflecting reliability of the obtained results, but the data indicate the prospects and effectiveness of cell therapy in the treatment of severe TBI.

Despite the abundant evidence that MSCs are promising in the treatment of TBI, a number of obstacles remain for the widespread adoption of this approach. One of the main problems in the use of MSCs is the limited understanding of how these cells "target" damaged tissues [7] and what specific neurotrophic factors contained in MSCs are responsible for the therapeutic mechanisms of action of MSCs [95]. It should be noted that there is objective evidence that MSCs exhibit immunosuppressive effects in inflammatory conditions $[96,97]$. Given that the secondary mechanisms of brain injury in TBI involve inflammatory response [98], the use of MSCs in treatment may cause unexpected effects [99].

H.J. Kim et al. [100] reported that although transplanted SCs in animal models survived for a long time, a small number of SCs differentiated into neurons and astrocytes. But the authors explain restoration of brain functions not by this effect, but by an increase in the levels of NGF, BDNF, and neurotrophin-3 in brain, since the release of these neurotrophic factors from SCs was accompanied by inhibition of apoptosis. This confirms the opinion of the authors of the article that SCs affect the focus of brain damage through trophic factors secreted with exosomes, but not through restoration of brain cellular pool.

The use of MSCs to treat TBI has generated tremendous interest over the past decade. This is because the technology for MSCs culturing is available. The supposed role of MSCs in TBI treatment is determined by the effect of trophic factors secreted by MSCs on "survived" neural networks of patient's brain. Neurotrophic factors of MSCs reduce inflammation in brain tissue of the recipient, which altogether contribute to increase in efficiency of preserved neural networks functioning in the brain of patients after TBI $[101,102]$.

The paracrine mechanisms of MSCs action in restoration of damaged tissues in TBI require further research [103]. Recently, there have been concerns about the possible role of MSCs in development of cancer and autoimmune diseases. This potential side effect also requires further research [11, 104]. 


\section{CONCLUSIONS}

The effectiveness of intranasal perineural implantation of MSCs in the complex therapy of patients with TBI has been demonstrated. The mechanisms of the beneficial effects of perineural implantation of MSCs in patients with TBI require further research.

\section{Contributors}

AZ, SK, VG, VN did the literature search and drafted the paper. SK, YT, ZK cultured stem cells.

YS, VA, AT, MN, LN operated on patients. VA and YS put forward the hypothesis and revised the manuscript.

All the authors have read and agreed to the final manuscript.

\section{Declaration of interests}

We declare no competing interests.

\section{Funding}

This research did not receive any specific grant from funding agencies in the public, commercial, or not-forprofit sectors.

\section{Acknowledgments}

We apologize to all whose work we could not cite because of space limitations.

\section{Ethical Standards and Informed Consent}

All procedures followed were in accordance with the ethical standards of the responsible committee on human experimentation (institutional and national) and with the Helsinki Declaration of 1975, as revised in 2000. Informed consent was obtained from all patients for being included in the study. Additional informed consent was obtained from all individuals for whom identifying information is included in this article.

\section{REFERENCES}

1. Thornhill S., Teasdale G.M., Murray G.D., McEwen J, Roy CW, Penny KI. Disability in young people and adults one year after head injury: prospective cohort study. BMJ. 2000 Jun 17; 320(7250): 1631-5. DOI: https://doi:10.1136/bmj.320.7250.1631

2. Hyder A.A., Wunderlich C.A., Puvanachandra P., Gururaj G., Kobusingye O.C. The impact of traumatic brain injuries: a global perspective. NeuroRehabilitation. 2007; 22(5): 341-53. DOI: https://doi:10.3233/ NRE-2007-22502

3. Taylor C.A., Bell J.M., Breiding M.J., Xu L. Traumatic Brain Injury-Related Emergency Department Visits, Hospitalizations, and Deaths - United States, 2007 and 2013. MMWR Surveill Summ. 2017 Mar 17; 66(9): 1-16. DOI: https://doi: 10.15585/mmwr.ss6609a1

4. Heile A.M., Wallrapp C., Klinge P.M., Samii A., Kassem M., Silverberg G., Brinker T. Cerebral transplantation of encapsulated mesenchymal stem cells improves cellular pathology after experimental traumatic brain injury. Neurosci. Lett. 2009 Oct 9; 463: 176-81. DOI: https://doi:10.1016/j.neulet.2009.07.071

5. Chuang T.J., Lin K.C., Chio C.C., Wang C.C., Chang C.P., Kuo J.R. Effects of secretome obtained from nor- moxia-preconditioned human mesenchymal stem cells in traumatic brain injury rats. J. Trauma Acute Care Surg. 2012 Nov; 73: 1161-7. DOI: https://doi:10.1097/ TA.0b013e318265d128

6. Anbari F., Khalili M.A., Bahrami A.R., Khoradmehr A., Sadeghian F., Fesahat F., Nabi A. Intravenous transplantation of bone marrow mesenchymal stem cells promotes neural regeneration after traumatic brain injury. Neural Regen. Res. 2014 May 1; 9: 919-23. DOI: https:// doi:10.4103/1673-5374.133133

7. Karp J.M., Teo G.S.L. Mesenchymal stem cell homing: the devil is in the details. Cell Stem Cell. 2009 Mar 6; 4:206-16. DOI: https://doi:10.1016/j.stem.2009.02.001

8. Menge T., Zhao Y., Zhao J., Wataha K., Gerber M., Zhang J., Letourneau P., Redell J., Shen L., Wang J., Peng Z., Xue H., Kozar R., Cox C.S, Khakoo A.Y., Holcomb J.B., Dash P.K., Pati S. Mesenchymal stem cells regulate blood-brain barrier integrity through TIMP3 release after traumatic brain injury. Sci. Transl. Med. 2012 Nov 21; 4(161): 161ra150. DOI: https:// doi:10.1126/scitranslmed.3004660

9. Zhang Y., Chopp M., Meng Y., Katakowski M., Xin H., Mahmood A., Xiong Y. Effect of exosomes derived from multipluripotent mesenchymal stromal cells on functional recovery and neurovascular plasticity in rats after traumatic brain injury. J. Neurosurg. 2015 Apr; 122(4): 856-67. DOI: https://doi:10.3171/2014.11.JNS14770

10. Ma Z.-J., Yang J.-J., Lu Y.-B., Zhao-Yang Liu Z.-Y., Xue-Xi Wang X.-X. Mesenchymal stem cell-derived exosomes: Toward cell-free therapeutic strategies in regenerative medicine. World J. Stem Cells. 2020 Aug 26; 12(8): 814-840. DOI: https://doi: 10.4252/wjsc. $\mathrm{v} 12 . \mathrm{i} 8.814$

11. Ng S.Y., Lee A.Y.W. Traumatic Brain Injuries: Pathophysiology and Potential Therapeutic Targets. Front. Cell Neurosci. 2019 Nov 27; 13: 528. DOI: https:// doi: 10.3389/fncel.2019.00528

12. Lowry L.E., Herzig M.C., Christy B.A., Schäfer R., Pati S., Cap A.P., Bynum J.A. Neglected No More: Emerging Cellular Therapies in Traumatic Injury. Stem Cell Rev. Rep. 2021 Jan 8; 1-21. DOI: https://doi: 10.1007/ s12015-020-10086-7

13. Algattas H., Huang J.H. Traumatic brain injury pathophysiology and treatments: early, intermediate, and late phases post-injury. Int. J. Mol. Sci. 2013 Dec 30; 15: 309-41. DOI: https://doi:10.3390/ijms15010309

14. Prins M., Greco T., Alexander D., Giza C.C. The pathophysiology of traumatic brain injury at a glance. Dis. Model Mech. 2013 Nov; 6(6): 1307-15. DOI: https:// doi:10.1242/dmm.011585

15. Jalloh I., Carpenter K.L.H., Helmy A., Carpenter T.A., Menon D.K., Hutchinson P.J. Glucose metabolism following human traumatic brain injury: methods of assessment and pathophysiological findings. Metab. Brain Dis. 2015 Jun; 30: 615-32. DOI: https://doi:10.1007/ s11011-014-9628-y

16. Johnson V.E., Stewart W., Smith D.H. Axonal pathology in traumatic brain injury. Exp. Neurol. 2013 
Aug; 246: 35-43. DOI: https://doi:10.1016/j. expneurol.2012.01.013

17. Werner C. Traumatic Brain Injury. 2017. DOI: http:// www.mayfieldclinic.com/PE-TBI.htm

18. Dardiotis E., Karanikas V., Paterakis K., Fountas K., Hadjigeorgiou G.M. Traumatic brain injury and inflammation: emerging role of innate and adaptive immunity. In: Agrawal A., Editor. Brain Injury - Pathogenesis, Monitoring, Recovery and Management. Rijeka: InTech. 2012: 23-38. DOI: https://doi: 10.5772/27840

19. Silver J., Miller J.H. Regeneration beyond the glial scar. Nat. Rev. Neurosci. 2004 Feb; 5(2): 146-56. DOI: https://doi:10.1038/nrn1326

20. Myer D., Gurkoff G., Lee S., Hovda D., Sofroniew M. Essential protective roles of reactive astrocytes in traumatic brain injury. Brain. 2006 Oct; 129: 2761-72. DOI: https://doi:10.1093/brain/awl165

21. Maas A.I., Stocchetti N., Bullock R. Moderate and severe traumatic brain injury in adults. Lancet Neurol. 2008 Aug; 7(8): 728-41. DOI: https://doi:10.1016/ S1474-4422(08)70164-9

22. Rolls A., Shechter R., Schwartz M. The bright side of the glial scar in CNS repair. Nat. Rev. Neurosci. 2009 Mar; 10: 235-41. DOI: https://doi:10.1038/nrn2591

23. Lucas S., Rothwell N.J., Gibson R.M. The role of inflammation in CNS injury and disease. Br. J. Pharmacol. 2006 Jan; 147: S232-40. DOI: https://doi:10.1038/ sj.bjp.0706400

24. Woodbury D., Schwarz E.J., Prockop D.J., Black I.B. Adult rat and human bone marrow stromal cells differentiate into neurons. J. Neurosci. Res. 2000 Aug; 61: 364-70. DOI: https://doi:10.1002/10974547(20000815)61:4<364::AID-JNR2>3.0.CO;2-C

25. Toma C., Pittenger M.F., Cahill K.S., Byrne B.J., Kessler P.D. Human mesenchymal stem cells differentiate to a cardiomyocyte phenotype in the adult murine heart. Circulation. 2002 Jan; 105(1): 93-8. doi:10.1161/ hc0102.101442

26. Horwitz E., Le Blanc K., Dominici M., Mueller I., Slaper-Cortenbach I., Marini F.C., Deans R.J., Krause D.S., Keating A.; International Society for Cellular Therapy. Clarification of the nomenclature for MSC: the International Society for Cellular Therapy position statement. Cytotherapy. 2005 7(5): 393-5. DOI: https:// doi:10.1080/14653240500319234

27. Dominici M., Le Blanc K., Mueller I., Slaper-Cortenbach I., Marini F., Krause D., Deans R., Keating A., Prockop Dj., Horwitz E. Minimal criteria for defining multipotent mesenchymal stromal cells. The International Society for Cellular Therapy position statement. Cytotherapy. 2006 8(4): 315-7. DOI: https:// doi:10.1080/14653240600855905

28. da Silva Meirelles L., Chagastelles P.C., Nardi N.B. Mesenchymal stem cells reside in virtually all post-natal organs and tissues. J. Cell Sci. 2006 Jun 1; 119(Pt 11): 2204-13. DOI: https://doi:10.1242/jcs.02932

29. Mahmood A., Lu D., Qu C., Goussev A., Chopp M. Long-term recovery after bone marrow stromal cell treatment of traumatic brain injury in rats. J. Neurosurg. 2006 Feb; 104(2): 272-7. DOI: https:// doi:10.3171/jns.2006.104.2.272

30. Chamberlain G., Fox J., Ashton B., Middleton J. Concise review: mesenchymal stem cells: their phenotype, differentiation capacity, immunological features, and potential for homing. Stem Cells. 2007 Nov; 25(11): 2739-49. DOI: https://doi:10.1634/stemcells.2007-0197

31. Meirelles Lda. S., Fontes A.M., Covas D.T., Caplan A.I. Mechanisms involved in the therapeutic properties of mesenchymal stem cells. Cytokine Growth Factor Rev. 2009 Oct-Dec; 20(5-6): 419-27. DOI: https:// doi:10.1016/j.cytogfr.2009.10.002

32. Walker P.A., Shah S.K., Harting M.T., Cox C.S. Progenitor cell therapies for traumatic brain injury: barriers and opportunities in translation. Dis. Models Mech. 2009 Jan-Feb; 2(1-2): 23-38. DOI: https:// doi:10.1242/dmm.001198

33. Ponte A.L., Marais E., Gallay N., Langonne A., Delorme B., Herault O., Charbord P., Domenech J. The in vitro migration capacity of human bone marrow mesenchymal stem cells: comparison of chemokine and growth factor chemotactic activities. Stem Cells. 2007 Jul; 25(7): 1737-45. DOI: https://doi:10.1634/ stemcells.2007-0054

34. Rüster B., Göttig S., Ludwig R.J., Bistrian R., Müller S., Seifried E., Gille J., Henschler R. Mesenchymal stem cells display coordinated rolling and adhesion behavior on endothelial cells. Blood. 2006 Dec 1; 108(12): 3938-44. DOI: https://doi:10.1182/blood-2006-05-025098

35. Segers V.F., Van Riet I., Andries L.J., Lemmens K., Demolder M.J., De Becker A.J., Kockx M.M., De Keulenaer G.W. Mesenchymal stem cell adhesion to cardiac microvascular endothelium: activators and mechanisms. Am. J. Physiol. Heart Circ. Physiol. 2006 Apr; 290(4): H1370-7. DOI: https://doi:10.1152/ ajpheart.00523.2005

36. Rojas M., Xu J., Woods C.R., Mora A.L., Spears W., Roman J., Brigham K.L. Bone marrow-derived mesenchymal stem cells in repair of the injured lung. Am. J. Respir. Cell Mol. Biol. 2005 Aug; 33(2): 145-52. DOI: https:// doi:10.1165/rcmb.2004-0330OC

37. Munoz J.R., Stoutenger B.R., Robinson A.P., Spees J.L., Prockop D.J. Human stem/progenitor cells from bone marrow promote neurogenesis of endogenous neural stem cells in the hippocampus of mice. Proc. Natl. Acad. Sci. USA. 2005 Dec 13; 102(50): 18171-6. DOI: https://doi:10.1073/pnas.0508945102

38. Hoogduijn M.J., Popp F., Verbeek R., Masoodi M., Nicolaou A., Baan C., Dahlke M.-H. The immunomodulatory properties of mesenchymal stem cells and their use for immunotherapy. Int. Immunopharmacol. 2010 Dec; 10(12): 1496-500. DOI: https://doi:10.1016/j. intimp.2010.06.019

39. Galindo L.T., Filippo T.R., Semedo P., Ariza C.B., Moreira C.M., Camara N.O.S., Porcionatto M.A. Mesenchymal stem cell therapy modulates the inflammatory response in experimental traumatic brain inju- 
ry. Neurol. Res. Int. 2011; 2011: 564089. DOI: https:// doi:10.1155/2011/564089

40. Bartholomew A., Sturgeon C., Siatskas M., Ferrer K., McIntosh K., Patil S., Hardy W., Devine S., Ucker D., Deans R., Moseley A., Hoffman R. Mesenchymal stem cells suppress lymphocyte proliferation in vitro and prolong skin graft survival in vivo. Exp. Hematol. 2002 Jan; 30(1): 42-8. DOI: https://doi:10.1016/ S0301-472X(01)00769-X

41. Di Nicola M., Carlo-Stella C., Magni M., Milanesi M., Longoni P.D., Matteucci P., Grisanti S., Gianni A.M. Human bone marrow stromal cells suppress T-lymphocyte proliferation induced by cellular or nonspecific mitogenic stimuli. Blood. 2002 May 15; 99(10): 383843. DOI: https://doi:10.1182/blood.V99.10.3838

42. Daadi M.M., Li Z., Arac A., Grueter B.G., Sofilos M., Malenka R.C., Wu J.C., Steinberg G.K. Molecular and Magnetic Resonance Imaging of Human Embryonic Stem Cell-Derived Neural Stem Cell Grafts in Ischemic Rat Brain. Molecular Therapy. 2009 Jul; 17(7): 1282-91. DOI: https://doi: 10.1038/mt.2009.104

43. López-Bendito G, Arlotta P. Cell replacement therapies for nervous system regeneration. Dev. neurobiology. 2012 Feb; 72(2): 145-52. DOI: https://doi:10.1002/ dneu.20897

44. Roybon L., Lamas N.J., Garcia A.D., Yang E.J., Sattler R., Lewis V.J., Kim Y.A., Kachel C.A., Rothstein J.D., Przedborski S., Wichterle H., Henderson C.E. Human stem cell-derived spinal cord astrocytes with defined mature or reactive phenotypes. Cell Rep. 2013 Sep 12; 4(5): 1035-48. DOI: https://doi:10.1016/j.celrep.2013.06.021

45. Barnabe G.F., Schwindt T.T., Calcagnotto M.E., Motta F.L., Martinez G. Jr, de Oliveira A.C., Keim L.M., D'Almeida V., Mendez-Otero R., Mello L.E. Chemically-induced RAT mesenchymal stem cells adopt molecular properties of neuronal-like cells but do not have basic neuronal functional properties. PLoS One. 2009 Apr 16; 4(4): e5222. DOI: https://doi:10.1371/journal. pone. 0005222

46. Zanier E.R., Pischiutta F., Riganti L., Marchesi F., Turola E., Fumagalli S., Perego C., Parotto E., Vinci P., Veglianese P., D’Amico G., Verderio C., De Simoni M.-G. Bone marrow mesenchymal stromal cells drive protective M2 microglia polarization after brain trauma. Neurotherapeutics. 2014 Jul; 11(3): 679-95. DOI: https://doi:10.1007/s13311-014-0277-y

47. Zane B. The Hayflick Limit. The Embryo Project Encyclopedia. 2019. DOI: https://embryo.asu.edu

48. Giraldi-Guimarães A., de Freitas H.T., Coelho B. de P., Macedo-Ramos H., Mendez-Otero R., Cavalcante L.A., Baetas-da-Cruz W. Bone marrow mononuclear cells and mannose receptor expression in focal cortical ischemia. Brain Res. 2012 May 3; 1452: 173-84. DOI: https://doi:10.1016/j.brainres.2012.03.002

49. Brenneman M., Sharma S., Harting M., Strong R., Cox C.S. Jr, Aronowski J., Grotta J.C., Savitz S.I. Autologous bone marrow mononuclear cells enhance recovery after acute ischemic stroke in young and middle-aged rats.
J. Cereb. Blood Flow Metab. 2010 Jan; 30(1): 140-9. DOI: https://doi:10.1038/jcbfm.2009.198

50. Bakondi B., Shimada I.S., Peterson B.M., Spees J.L. SDF-1 $\alpha$ secreted by human CD133-derived multipotent stromal cells promotes neural progenitor cell survival through CXCR7. Stem Cells Dev. 2011 Jun; 20(6): 1021-9. DOI: https://doi:10.1089/scd.2010.0198

51. Bao X., Wei J., Feng M., Lu S., Li G., Dou W., Ma W., Ma S., An Y., Qin C., Zhao R.C., Wang R. Transplantation of human bone marrow-derived mesenchymal stem cells promotes behavioral recovery and endogenous neurogenesis after cerebral ischemia in rats. Brain Res. 2011 Jan 7; 1367: 103-13. DOI: https://doi:10.1016/j. brainres.2010.10.063

52. Ranganath S.H., Levy O., Inamdar M.S., Karp J.M. Harnessing the mesenchymal stem cell secretome for the treatment of cardiovascular disease. Cell Stem Cell. 2012 Mar 2; 10(3): 244-58. DOI: https://doi: 10.1016/j. stem.2012.02.005

53. Andres R.H., Horie N., Slikker W., Keren-Gill H., Zhan K., Sun G., Manley N.C., Pereira M.P., Sheikh L.A., McMillan E.L., Schaar B.T., Svendsen C.N., Bliss T.M., Steinberg G.K. Human neural stem cells enhance structural plasticity and axonal transport in the ischaemic brain. Brain. 2011 Jun; 134(Pt6): 1777-89. DOI: https://doi: 10.1093/brain/awr094

54. Hawryluk G.W., Mothe A.J., Chamankhah M., Wang J., Tator C., Fehlings M.G. In vitro characterization of trophic factor expression in neural precursor cells. Stem Cells Dev. 2012 Feb 10; 21(3): 432-47. DOI: https:// doi: $10.1089 / \mathrm{scd} .2011 .0242$

55. Xin H., Li Y., Buller B., Katakowski M., Zhang Y., Wang X., Shang X., Zhang Z.G., Chopp M. Exosome-mediated transfer of miR-133b from multipotent mesenchymal stromal cells to neural cells contributes to neurite outgrowth. Stem Cells. 2012 Jul; 30(7): 155664. DOI: https://doi: 10.1002/stem.1129

56. van Velthoven C.T., Kavelaars A., van Bel F., Heijnen C.J. Nasal administration of stem cells: a promising novel route to treat neonatal ischemic brain damage. Pediatr. Res. 2010 Nov; 68(5): 419-22. DOI: https:// doi: 10.1203/PDR.0b013e3181f1c289

57. Gardner R.C., Yaffe K. Traumatic brain injury may increase risk of young onset dementia. Ann. Neurol. 2014 Mar; 75(3): 339-41. DOI: https://doi:10.1002/ ana. 24121

58. Grigorian A., Gilerovich E., Pavlichenko N., Kruglyakov P., Sokolova I., Polyntsev D. Effect of transplantation of mesenchymal stem cells on neuronal survival and formation of a glial scar in the brain of rats with severe traumatic brain injury. Bull. Exp. Biol. Med. 2011 Feb; 150(4): 551-5. DOI: https://doi: 10.1007/s10517-011-1187-1

59. Connick P., Patani R., Chandran S. Stem cells as a resource for regenerative neurology. Pract. Neurol. 2011 Feb; 11(1): 29-36. DOI: https://doi: 10.1136/jnnp.2010.235184

60. Wilson J.T., Pettigrew L.E., Teasdale G.M. Structured interviews for the Glasgow Outcome Scale and the 
extended Glasgow Outcome Scale: guidelines for their use. J. Neurotrauma. 1998 Aug; 15(8): 573-85. DOI: https://doi: 10.1089/neu.1998.15.573

61. Li Z.M., Zhang Z.T., Guo C.J. Geng F.Y., Qiang F., Wang L.X. Autologous bone marrow mononuclear cell implantation for intracerebral hemorrhage - a prospective clinical observation. Clin. Neurol. Neurosurg. 2013 Jan; 115(1): 72-6. DOI: https://doi: 10.1016/j. clineuro.2012.04.030

62. Meltzer C.C., Kondziolka D., Villemagne V.L., Wechsler L., Goldstein S., Thulborn K.R., Gebel J., Elder E.M., DeCesare S., Jacobs A. Serial [18F] fluorodeoxyglucose positron emission tomography after human neuronal implantation for stroke. Neurosurgery. 2001 Sep; 49(3): 586-91; discussion 591-2. DOI: https://doi: 10.1097/00006123-200109000-00011

63. Nelson P.T., Kondziolka D., Wechsler L., Goldstein S., Gebel J., DeCesare S., Elder E.M., Zhang P.J., Jacobs A., McGrogan M., Lee V.M.-Y., Trojanowski J.Q. Clonal human (hNT) neuron grafts for stroke therapy: neuropathology in a patient 27 months after implantation. Am. J. Pathol. 2002 Apr; 160(4): 1201-6. DOI: https://doi: 10.1016/S0002-9440(10)62546-1

64. Kondziolka D., Wechsler L., Goldstein S., Meltzer C., Thulborn K.R., Gebel J., Jannetta P., DeCesare S., Elder E.M., McGrogan M., Reitman M.A., Bynum L. Transplantation of cultured human neuronal cells for patients with stroke. Neurology. 2000 Aug 22; 55(4): 565-9. DOI: https://doi: 10.1212/wnl.55.4.565

65. Kondziolka D., Steinberg G.K., Wechsler L., Meltzer C.C., Elder E., Gebel J., Decesare S., Jovin T., Zafonte R., Lebowitz J., Flickinger J.C., Tong D., Marks M.P., Jamieson C., Luu D., Bell-Stephens T., Teraoka J. Neurotransplantation for patients with subcortical motor stroke: a phase 2 randomized trial. J. Neurosurg. 2005 Jul; 103(1): 38-45. DOI: https://doi: 10.3171/ jns.2005.103.1.0038

66. Suárez-Monteagudo C., Hernández-Ramírez P., Alvarez-González L., García-Maeso I., de la Cuétara-Bernal K., Castillo-Díaz L., Bringas-Vega M.L., Martínez-Aching G., Morales-Chacón L.M., Báez-Martín M.M., Sánchez-Catasús C., Carballo-Barreda M., Rodríguez-Rojas R., Gómez-Fernández L., Alberti-Amador E., Macías-Abraham C., Balea E.D., Rosales L.C., Del Valle Pérez L., Ferrer B.B.S., González R.M., Bergado J.A. Autologous bone marrow stem cell neurotransplantation in stroke patients. An open study. Restor. Neurol. Neurosci. 2009; 27(3): 151-61. DOI: https:// doi: 10.3233/RNN-2009-0483

67. Li L., Jiang Q., Qu C.S., Ding G.L., Li Q.J., Wang S.Y., Lee J.H., Lu M., Mahmood A., Chopp M. Transplantation of marrow stromal cells restores cerebral blood flow and reduces cerebral atrophy in rats with traumatic brain injury: in vivo MRI study. J. Neurotrauma. 2011 Apr; 28(4): 535-45. DOI: https://doi: 10.1089/neu.2010.1619

68. Rabinovich S.S, Seledtsov V.I., Banul N.V., Poveshchenko O.V., Senyukov V.V., Astrakov S.V., Samarin D.M., Taraban V.Y. Cell therapy of brain stroke. Bull.
Exp. Biol. Med. 2005 Jan; 139(1): 126-8. DOI: https:// doi: 10.1007/s10517-005-0229-y

69. Schepici G., Silvestro S., Bramanti P., Mazzon E. Traumatic Brain Injury and Stem Cells: An Overview of Clinical Trials, the Current Treatments and Future Therapeutic Approaches. Medicina (Kaunas). 2020 Mar 19; 56(3): 137. DOI: https://doi:10.3390/ medicina56030137

70. Barbosa da Fonseca L.M., Gutfilen B., Rosado de Castro P.H. Battistella V., Goldenberg R.C., Kasai-Brunswick T., Chagas C.L., Wajnberg E., Maiolino A., Salles Xavier S., Andre C., Mendez-Otero R., de Freitas G.R. Migration and homing of bone-marrow mononuclear cells in chronic ischemic stroke after intra-arterial injection. Exp. Neurol. 2010 Jan; 221(1): 122-8. DOI: https://doi: 10.1016/j. expneurol.2009.10.010

80. Rosado-de-Castro P.H., Pimentel-Coelho P.M., Fonseca L.M., Freitas G.R., Mendez-Otero R. The rise of cell therapy trials for stroke: review of published and registered studies. Stem Cells Dev. 2013 Aug 1; 22(15): 2095-111. DOI: https://doi: 10.1089/scd.2013.0089

81. Friedrich M.A., Martins M.P., Araújo M.D., Klamt C., Vedolin L., Garicochea B., Raupp E.F., Sartori El Ammar J., Machado D.C., Costa J.C., Nogueira R.G., Rosado-de-Castro P.H., Mendez-Otero R., Freitas G.R. Intra-arterial infusion of autologous bone marrow mononuclear cells in patients with moderate to severe middle cerebral artery acute ischemic stroke. Cell Transplant. 2012; 21 Suppl. 1: S13-21. DOI: https://doi: $10.3727 / 096368912 \times 612512$

82. Jiang Y., Zhang M.J., Hu B.Y. Specification of functional neurons and glia from human pluripotent stem cells. Protein Cell. 2012 Nov; 3(11): 818-25. DOI: https://doi: 10.1007/s13238-012-2086-6

83. Walczak P., Zhang J., Gilad A.A., Kedziorek D.A., Ruiz-Cabello J., Young R.G., Pittenger M.F., van Zijl P.C., Huang J., Bulte J.W. Dual-modality monitoring of targeted intraarterial delivery of mesenchymal stem cells after transient ischemia. Stroke. 2008 May; 39(5): 1569-74. DOI: https://doi: 10.1161/ STROKEAHA.107.502047

84. England T.J., Abaei M., Auer D.P., Lowe J., Jones D.R., Sare G., Walker M., Bath P.M. Granulocyte-colony stimulating factor for mobilizing bone marrow stem cells in subacute stroke: the stem cell trial of recovery enhancement after stroke 2 randomized controlled trial. Stroke. 2012 Feb; 43(2): 405-11. DOI: https://doi: 10.1161/STROKEAHA.111.636449

85. Bang O.Y., Lee J.S., Lee P.H., Lee G. Autologous mesenchymal stem cell transplantation in stroke patients. Ann. Neurol. 2005 Jun; 57(6): 874-82. DOI: https://doi: 10.1002/ana.20501

86. Honmou O., Houkin K., Matsunaga T., Niitsu Y., Ishiai S., Onodera R., Waxman S.G., Kocsis J.D. Intravenous administration of auto serum-expanded autologous mesenchymal stem cells in stroke. Brain. 2011 Jun; 134(Pt 6): 1790-807. DOI: https://doi: 10.1093/brain/awr063

87. Bhasin A., Srivastava M.V., Kumaran S.S., Mohanty 
S., Bhatia R., Bose S., Gaikwad S., Garg A., Airan B. Autologous mesenchymal stem cells in chronic stroke. Cerebrovasc. Dis. Extra. 2011 Jan-Dec; 1(1): 93-104. DOI: https://doi: 10.1159/000333381

88. Kamiya N., Ueda M., Igarashi H., Nishiyama Y., Suda S., Inaba T., Katayama Y. Intra-arterial transplantation of bone marrow mononuclear cells immediately after reperfusion decreases brain injury after focal ischemia in rats. Life Sci. 2008 Sep 12; 83(11-12): 433-7. DOI: https://doi: 10.1016/j.lfs.2008.07.018

89. Vasconcelos-dos-Santos A., Rosado-de-Castro P.H., Lopes de Souza S.A., da Costa Silva J., Ramos A.B., Rodriguez de Freitas G., Barbosa da Fonseca L.M., Gutfilen B., Mendez-Otero R. Intravenous and intra-arterial administration of bone marrow mononuclear cells after focal cerebral ischemia: Is there a difference in biodistribution and efficacy? Stem Cell Res. 2012 Jul; 9(1): 1-8. DOI: https://doi: 10.1016/j.scr.2012.02.002

90. Zhang L., Li Y., Romanko M., Kramer B.C., Gosiewska A., Chopp M., Hong K. Different routes of administration of human umbilical tissue-derived cells improve functional recovery in the rat after focal cerebral ischemia. Brain Res. 2012 Dec 13; 1489: 104-12. DOI: https://doi: 10.1016/j.brainres.2012.10.017

91. Lees J.S., Sena E.S., Egan K.J., Antonic A., Koblar S.A., Howells D.W., Macleod M.R. Stem cell-based therapy for experimental stroke: a systematic review and meta-analysis. Int. J. Stroke. 2012 Oct; 7(7): 582-8. DOI: https://doi: 10.1111/j.1747-4949.2012.00797.x

92. Kenmuir C.L., Wechsler L.R. Update on cell therapy for stroke. Stroke Vasc. Neurol. 2017 May 22; 2(2): 59-64. DOI: https://doi:10.1136/svn-2017-000070. eCollection 2017 Jun

93. Shanko Y., Navitskaya V., Zamaro A., Zafranskaya M., Krivenko S., Koulchitsky S., Takalchik-Stukach Y., Smeyanovich A., Nizheharodova D., Pashkevich S., Dosina M., Denisov A., Kulchitsky V. Somatotopic principle of perineural implantation of stem cells in patients with brain injuries. J. Neurol. Stroke. 2018 Oct; 8(5): 259-61. DOI: https://doi: 10.15406/ jnsk.2018.08.00321

94. Bogodvid T., Pashkevich S., Dosina M., Zamaro A., Takalchik Y., Yafarova G., Andrianov V., Denisov A., Loiko D., Gainutdinov K., Kulchitsky V. Effect of intranasal administration of mesenchymal stem cells on the approximate motor activity of rats after simulation of ischemic stroke. Eur. J. Clin. Investig. 2019; 49 (Suppl 1, P146-T): 161. DOI: https://doi: 10.1111/eci.13109

95. Danielyan L., Schäfer R., von Ameln-Mayerhofer A., Buadze M., Geisler J., Klopfer T., Burkhardt U., Proksch B., Verleysdonk S., Ayturan M., Buniatian G.H., Gleiter C.H., Frey W.H. Intranasal delivery of cells to the brain. Eur. J. Cell Biol. 2009 Jun; 88(6): 315-24. DOI: https://doi: 10.1016/j.ejcb.2009.02.001

96. Kulchitsky V., Zamaro A., Shanko Y., Koulchitsky S. Prospects of Perineural Implantation of Stem Cells in Recovery of Neural Network's Functions in Brain Diseases. Biomed. J. Sci. Tech. Res. 2018
Oct 26; 10(3) 7834-37. DOI: https://doi: 10.26717/ BJSTR.2018.10.001959

97. Kulchitsky V., Zamaro A., Shanko Y., Koulchitsky S. Positive and negative aspects of cell technologies in cerebral diseases. J. Neurol. Stroke. 2018 Mar 15; 8(2): 87-88. DOI: https://doi.org/10.15406/ jnsk.2018.08.00286

98. Kjell J., Fischer-Sternjak J., Thompson A.J., Friess C., Sticco M.J., Salinas F., Cox J., Martinelli D.C., Ninkovic J., Franze K., Schiller H.B., Götz M. Defining the Adult Neural Stem Cell Niche Proteome Identifies Key Regulators of Adult Neurogenesis. Cell Stem Cell. 2020 Feb 6; 26(2): 277-293.e8. DOI: https://doi: 10.1016/j. stem.2020.01.002

99. Cox C.S., Hetz R.A., Liao G.P., Aertker B.M., Ewing-Cobbs L., Juranek J., Savitz S.I., Jackson M.L., Romanowska-Pawliczek A.M., Triolo F., Dash P.K., Pedroza C., Lee D.A., Worth L., Aisiku I.P., Choi H.A., Holcomb J.B., Kitagawa R.S. Treatment of severe adult traumatic brain injury using bone marrow mononuclear cells. Stem Cells. 2017 Apr; 35(4): 1065-79. DOI: https://doi: 10.1002/stem.2538

100. Wang S., Cheng H., Dai G., Wang X., Hua R., Liu X., Wang P., Chen G., Yue W., An Y. Umbilical cord mesenchymal stem cell transplantation significantly improves neurological function in patients with sequelae of traumatic brain injury. Brain Res. 2013 Sep 26; 1532: 76-84. DOI: https://doi: 10.1016/j.brainres.2013.08.001

101. Liao G.P., Harting M.T., Hetz R.A., Liao G.P., Harting M.T., Hetz R.A., Walker P.A., Shah S.K., Corkin C.J., Hughes T.G., Jimenez F., Kosmach S.C., Day M.-C., Tsao K., Lee D.A., Worth L.L., Baumgartner J.E., Cox C.S. Autologous bone marrow mononuclear cells reduce therapeutic intensity for severe traumatic brain injury in children. Pediatr. Crit. Care Med. 2015 Mar; 16(3): 245-55. DOI: https://doi: 10.1097/ PCC.0000000000000324

102. Tian C., Wang X., Wang X., Wang L., Wang X., Wu S., Wan Z. Autologous bone marrow mesenchymal stem cell therapy in the subacute stage of traumatic brain injury by lumbar puncture. Exp. Clin. Transplant. 2013 Apr; 11(2): 176-81. DOI: https://doi: 10.6002/ect.2012.0053

103. Zhang Z.X., Guan L.X., Zhang K., Zhang Q., Dai L.J. A combined procedure to deliver autologous mesenchymal stromal cells to patients with traumatic brain injury. Cytotherapy. 2008; 10(2): 134-9. DOI: https:// doi: 10.1080/14653240701883061

104. Torrente D., Avila M., Cabezas R., Morales L., Gonzalez J., Samudio I., Barreto G.E. Paracrine factors of human mesenchymal stem cells increase wound closure and reduce reactive oxygen species production in a traumatic brain injury in vitro model. Hum. Exp. Toxicol. 2014 Jul; 33(7): 673-84. DOI: https://doi: $10.1177 / 0960327113509659$

105. Kulchitsky V., Zamaro A., Navitskaya V., Koulchitsky S., Shanko Y. Regulatory Effects of Mesenchymal Stem Cells in Brain. Biomed. J. Sci. Tech. Res. 
2018 Nov 14; 11(1): 1-3. DOI: https://doi: $10.26717 /$ BJSTR.2018.11.002039

106. Najar M., Raicevic G., Fayyad-Kazan H., De Bruyn C., Bron D., Toungouz M., Lagneaux L. Impact of different mesenchymal stromal cell types on T-cell activation, proliferation and migration. Int. Immunopharmacol. 2013 Apr; 15(4): 693-702. DOI: https://doi: 10.1016/j. intimp.2013.02.020.

107. Lenzlinger P.M., Morganti-Kossmann M.-C., Laurer H.L., McIntosh T.K. The duality of the inflammatory response to traumatic brain injury. Mol. Neurobiol. 2001 Aug-Dec; 24(1-3): 169-81. DOI: https://doi: 10.1385/MN:24:1-3:169

108. Kouroupis D., Correa D. Increased Mesenchymal Stem Cell Functionalization in Three-Dimensional Manufacturing Settings for Enhanced Therapeutic Applications. Front. Bioeng. Biotechnol. 2021 Feb 12; 9: 621748. DOI: https://doi: 10.3389/fbioe.2021.621748.

109. Kim H.-J., Lee J.-H., Kim S.-H. Therapeutic effects of human mesenchymal stem cells on traumatic brain injury in rats: secretion of neurotrophic factors and inhibition of apoptosis. J Neurotrauma. 2010 Jan; 27(1): 131-8. DOI: https://doi: 10.1089/neu.2008-0818

110. Kumagai G., Tsoulfas P., Toh S., McNiece I., Bramlett
H.M., Dietrich W.D. Genetically modified mesenchymal stem cells (MSCs) promote axonal regeneration and prevent hypersensitivity after spinal cord injury. Exp. Neurol. 2013 Oct; 248: 369-80. DOI: https:// doi:10.1016/j.expneurol.2013.06.028

111. Mead B., Scheven B.A. Mesenchymal stem cell therapy for retinal ganglion cell neuroprotection and axon regeneration. Neural Regen. Res. 2015 Mar; 10(3): 371-3. DOI: https://doi:10.4103/1673-5374.153681

112. Parr A.M., Tator C.H., Keating A. Bone marrow-derived mesenchymal stromal cells for the repair of central nervous system injury. Bone Marrow Transplant. 2007 Oct; 40(7): 609-19. DOI: https://doi:10.1038/ sj.bmt. 1705757

113. Djouad F., Plence P., Bony C., Tropel P., Apparailly F., Sany J., Noël D., Jorgensen C. Immunosuppressive effect of mesenchymal stem cells favors tumor growth in allogeneic animals. Blood. 2003 Nov 15; 102(10): 3837-44. DOI: https://doi:10.1182/blood-2003-04-1193

Article history Received: 05.03.2021 Revision requested: 14.03 .2021 Revision received: 26.03 .2021 Accepted: 29.03 .2021 Published: 31.03 .2021

\title{
МЕЗЕНХІМАЛЬНІ СТОВБУРОВІ КЛІТИНИ У КОМПЛЕКСНОМУ ЛІКУВАННІ ТРАВМИ МОЗКУ
}

\author{
${ }^{1}$ Шанько Ю.Г., ${ }^{2}$ Кривенко С.І., ${ }^{3}$ Гончаров В.В., ${ }^{1}$ Новицька В.В., ${ }^{4}$ Замаро А.С., ${ }^{1}$ Танін А.Л., \\ ${ }^{1}$ Нехай М.А., ${ }_{4}^{4}$ Токальчік Ю.П., ${ }^{1}$ Новикова Л.А., ${ }^{5}$ Колядич 3.В., 4 Кульчицький В.А. \\ ${ }^{1}$ Республиканский научно-практический центр неврологии и нейрохирургии, Минск, Беларусь \\ 29 Городская клиническая больница, Минск, Беларусь \\ ${ }^{3}$ Городская клиническая больница скорой медицинской помощи, Минск, Беларусь \\ ${ }^{4}$ Институт физиологии Национальной академии наук, Минск, Беларусь \\ ${ }^{5}$ Государственное учреждение «Национальный онкологический центр Беларуси имени Н.Н. Александрова», \\ Лесной, Минский район, Беларусь \\ vladi@fizio.bas-net.by
}

Актуальність. Проблема ефективної профілактики і терапії травм головного мозку різної етіології не вирішена в усіх країнах світу. Первинне ураження мозку при травмі ініціює вторинні пошкодження нервової тканини. В результаті порушується взаємодія нейронних мереж головного мозку і послаблюється контроль соматичних і вісцеральних функцій організму. У статті на підставі власних клінічних спостережень і зіставлення результатів з літературними відомостями обговорюються перспективи застосування клітинних технологій для запобігання фатальних порушень контролю вітальних функцій після травматичного пошкодження мозку - traumatic brain injury (TBI).

Мета: оцінити ефективність застосування інтраназальної періневральної імплантації мезенхімальних стовбурових клітин (MSCs) у комплексній терапії пацієнтів з ТВI.

Матеріали та методи. У 15 пацієнтів з важкою ТВІ застосовували у комплексній терапії методику інтраназального періневрального введення MSCs. Вік пацієнтів $19 \div 69$ років; чоловіків 13 і 2 жінки. 3 жирової тканини черевної стінки пацієнта виділяли суспензію клітин, які центрифугували 10 хв зі швидкістю 1500 об/хв. Клітинний осад відмивали у фосфатному буферному розчині і в середовищі DMEM. Клітини культивували в пластикових культуральних флаконах у зволоженій атмосфері з 5\% вмістом $\mathrm{CO}_{2}$. У день імплантації клітинну масу трипсинізували за стандартною методикою і ресуспендували у фізіологічному розчині. Контролювали динаміку росту культури, поліпотентність, фенотипування MSCs. MSCs вводили під загальним наркозом в підслизову оболонку порожнини носа 3-4-кратно з інтервалом 3-7 днів, в залежності від темпів зростання MSCs, в разовій дозі від $12.0 \times 106$ до $35.0 \times 106$ клітин.

Результати. Використання в комплексному лікуванні хворих на важку ТВI алогенних і переважно аутологічних MSCs жирової тканини шляхом їх інтраназальної періневральної доставки в область травматичного ушкодження головного мозку не викликає ускладнень і є безпечним методом. У 8 пацієнтів з важкою ТВI функції мозку через 6 місяців за Glasgow Outcome Scale Extended оцінювалися від 4 до 7 балів, в середньому 5.4 \pm 1.1 бала. Основний результат полягає в тому, що проведення комп- 
лексної терапії, яка включає інтраназальну імплантацію MSCs в гострому і підгострому періоді важкої TBI, сприяє виживанню пацієнтів і відновленню контролю неврологічних, в тому числі когнітивних, функцій.

Висновки. Продемонстровано ефективність застосування інтраназальної періневральної імплантації MSCs у комплексній терапії пацієнтів з TBI. Механізми позитивних ефектів періневральної імплантації MSCs пацієнтам з ТВI вимагають додаткового вивчення.

Ключові слова: травма мозку, пацієнти, клітинна терапія, інтраназальний метод, механізми.

\title{
МЕЗЕНХИМАЛЬНЫЕ СТВОЛОВЫЕ КЛЕТКИ В КОМПЛЕКСНОМ ЛЕЧЕНИИ ТРАВМЫ МОЗГА
}

\author{
${ }^{1}$ Шанько Ю.Г., ${ }^{2}$ Кривенко С.И., ${ }^{3}$ Гончаров В.В., ${ }^{1}$ Новицкая В.В., ${ }^{4}$ Замаро А.S., \\ ${ }^{1}$ Танин А.Л., ${ }^{1}$ Нехай М.А., ${ }^{4}$ Токальчик Ю.П., ${ }^{1}$ Новикова Л.А., ${ }^{5}$ Колядич 3.В., ${ }^{4}$ Кульчицкий В.А. \\ ${ }^{1}$ Республиканский научно-практический ичентр неврологии и нейрохирургии, Минск, Беларусь \\ 29 Городская клиническая больница, Минск, Беларусь \\ ${ }^{3}$ Городская клиническая больница скорой медицинской помощи, Минск, Беларусь \\ ${ }^{4}$ Институт физиологии Наџииональной академии наук, Минск, Беларусь \\ ${ }^{5}$ Государственное учреждение «Национальный онкологический изентр Беларуси имени Н.Н. Александрова», \\ Лесной, Минский район, Беларусь \\ vladi@fizio.bas-net.by
}

Актуальность. Проблема эффективной профилактики и терапии травм головного мозга различной этиологии не решена во всех странах мира. Первичное поражение мозга при травме инициирует вторичные повреждения нервной ткани. В результате нарушается взаимодействие нейронных сетей головного мозга и ослабляется контроль соматических и висцеральных функций организма. В статье на основании собственных клинических наблюдений и сопоставления результатов с литературными сведениями обсуждаются перспективы применения клеточных технологий для предотвращения фатальных нарушений контроля витальных функций после травматического повреждения мозга - traumatic brain injury (TBI).

Цель: оценить эффективность применения интраназальной периневральной имплантации мезенхимальных стволовых клеток (MSCs) в комплексной терапии пациентов с TBI.

Материалы и методы. У 15 пациентов с тяжелой ТВІ применяли в комплексной терапии методику интраназального пе-

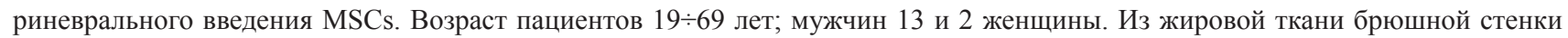
пациента выделяли суспензию клеток, которые центрифугировали 10 мин со скоростью 1500 об/мин. Клеточный осадок отмывали в фосфатном буферном растворе и в среде DMEM. Клетки культивировали в пластиковых культуральных флаконах в увлажненной атмосфере с $5 \%$ содержанием $\mathrm{CO}_{2}$. В день имплантации клеточную массу трипсинизировали по стандартной методике и ресуспендировали в физиологическом растворе. Контролировали динамику роста культуры, полипотентность, фенотипирование MSCs. MSCs вводили под общим наркозом в подслизистую оболочку полости носа 3-4-кратно с интервалом 3-7 дней, в зависимости от темпов роста MSCs, в разовой дозе от 12.0×106 до 35.0×106 клеток.

Результаты. Использование в комплексном лечении пациентов с тяжелой ТВІ аллогенных и преимущественно аутологичных MSCs жировой ткани путем их интраназальной периневральной доставки в область травматического повреждения головного мозга не вызывает осложнений и является безопасным методом. У 8 пациентов с тяжелой ТВІ функции мозга через 6 месяцев по Glasgow Outcome Scale Extended оценивались от 4 до 7 баллов, в среднем $5.4 \pm 1.1$ балла. Основной результат заключается в том, что проведение комплексной терапии, включающей интраназальную имплантацию MSCs в остром и подостром периоде тяжелой ТВI, способствует выживанию пациентов и восстановлению контроля неврологических, в том числе когнитивных, функций.

Выводы. Продемонстрирована эффективность применения интраназальной периневральной имплантации MSCs в комплексной терапии пациентов с TBI. Механизмы позитивных эффектов периневральной имплантации MSCs пациентам с TBI требуют дополнительного изучения.

Ключевые слова: травма мозга, пациенты, клеточная терапия, интраназальный метод, механизмы. 